\begin{tabular}{c} 
Volume and Issues Obtainable at Center for Sustainability Research and Consultancy \\
Sustainable Business and Society in Emerging Economies \\
ISSN: $2708-2504$ (E): 2708-2172 \\
Volume 2: No 1, June 2020 \\
CSRᄃ \\
Journal homepage: $\underline{\text { ww.publishing.globalcsrc.org/sbsee }}$ \\
\hline
\end{tabular}

\title{
A Global Research Trend on Organizational Citizenship Behaviour: A Bibliometric Analysis
}

\section{${ }^{1}$ Jen Ling Gan, ${ }^{2}$ Halimah Mohd Yusof}

${ }^{1}$ PhD Scholar, Azman Hashim International Business School, Universiti Teknologi Malaysia, Skudai, Johor, ganjenling@gmail.com

${ }^{2}$ Senior Lecturer, School of Human Resource Development and Psycholgy, Faculty of Social Sciences and Humanities, Universiti Teknologi Malaysia, Skudai, Johor, halimahmy@utm.my

\begin{tabular}{l}
$\quad$ ARTICLE DETAILS \\
\hline History \\
Revised format: May 2020 \\
Available Online: June 2020 \\
\hline Keywords \\
Organizational citizenship \\
behavior, Bibliometric Analysis, \\
Bibliographic Map, VOS Viewer
\end{tabular}

JEL Classification:

M20, M21

\section{ABSTRACT}

Objective: There are limited literatures that discussed on the trend of OCB. Hence, this bibliometric analysis is aimed to evaluate the global research growth to retrieve and analyse the publication on OCB. The bibliometric analysis is used to search the database of Scopus from the oldest publication in 1988 to the recent publication in 2019. The objectives were to evaluate the trend of OCB research, details of coauthorship, leading institutions and countries, top scholars, and leading author keywords.

Methodology: This study used VOS Viewer 1.6.11 to analyse and visualise the global research trend on $\mathrm{OCB}$ in analysing the bibliographic data. Bibliometric maps were retrieved from VOS Viewer 1.6.11.

Results: This study retrieved 2, 356 journal articles from Scopus database from 1988 to 2019. The publication's trend revealed that the number of publications has been increasing steadily since 2002 . The leading countries in OCB research are the United States and China. Among the fifteen leading universities, five of them were from the world's top 150 universities. Among the keywords, 'commitment' has the most link with $\mathrm{OCB}$, which indicated that OCB is active in the management field compared to other fields such as nursing and psychology..

Implication: This paper can be beneficial for academicians, organisations, and business policymakers in understanding the global trend of OCB besides discovering the future directions and opportunities for future studies.

Corresponding author's email address: ganjenling@ gmail.com

Recommended citation: Gan, J. L., \& Yusof, H. M. (2020). A Global Research Trend on Organizational Citizenship Behaviour: A Bibliometric Analysis. Sustainable Business and Society in Emerging Economies, 2(1), 55-71 


\section{Introduction}

The topic of sustainability management has been widely discussed in nowadays. Organizational citizenship behaviour (OCB), which is known as one of the contributors to the performance of sustainability, has been drawing attention in academic field (Wang et al., 2018). OCB is defined as employees' behaviour which is voluntary-based, not being recognised by formal reward system and formal job scopes, and could improve the performance of organization (Organ, 1988). Over the decades, many empirical studies had been conducted to examine the antecedents of OCB, as well as to investigate the outcomes of OCB. However, the global trend of OCB is yet to be discussed. The big picture of OCB trend could be served as guidance for future researchers in looking for new areas in OCB research. Therefore, this paper intended to present bibliometric analysis to outline the trend of OCB since 1988 to 2019.

Although the attention to OCB has been growing, the discussion of global research trend on OCB is still lacking. Yaylaci (2016) has presented the research trend of OCB from the year of 2000 to 2015. However, the scholar focused on single country, which is Turkey only. In addition to that, the scholar covered only the years from 2000 to 2015, where this is insufficient to get a complete big picture of OCB trend since beginning. On the other hand, Romeo Delgado et al. (2017) had also analysed the trend of OCB using bibliometric approach. However, only Web of Science (WOS) database's data was retrieved by the scholar, where the data could be limited from only one database. Although WOS and Scopus databases might consist of overlapping journal indexing, both databases index different journals as well (Aghaei Chadegani et al., 2013). Scopus is known as the biggest database that covers multidisciplinary research. Therefore, this paper was intended to conduct data mining via Scopus database to collect more research articles which may not available in WOS and may not discussed by Romeo Delgado et al. (2017) and Yaylaci (2016). One of the coverage differences between Scopus and WOS could be seen, where the oldest paper of OCB in Scopus was 1988, while the oldest paper in WOS was 1991. This proved that both databases cover different journals, resulting different findings on data mining.

This paper can be beneficial for academicians, organisations, and business policymakers in understanding the global trend of OCB besides discovering the new directions for future studies. The discussion of this paper has four objectives: (i) to investigate the trend's outline of 'OCB' article; (ii) to indicate the contribution of active scholars, nations, and organizations; (iii) to discover the terminology, concept, and topic of interest; and (iv) to provide new insight of potential international collaboration between countries, and future directions.

\section{Methods}

Bibliometric analysis can be conducted through collecting the bibliographic data of other scholars in the particular field, where those scholars communicated their thinking via citations or writing (Zupic and Carter, 2015). It is believed that bibliometric analysis is helpful in analysing the topic of interest in fields, as well as providing insight for future researchers (Khudzari et al., 2018). Bibliometric analysis focuses on the performance of publications in certain fields and explains the dynamics of the fields which are different from a review paper (Cobo et al., 2011).

\subsection{Search Strategy}

This study conducted data mining from October $7^{\text {th }}$ to $10^{\text {th }}, 2019$ in Scopus database by setting the central theme for the bibliometric analysis. The central theme for the research articles is "organizational citizenship behaviour" in the title and abstract to analyse the global research trend of OCB. The list of articles was sorted by years (oldest to latest) in which the oldest is 1988 and the latest is 2019. However, it was cautioned that OCB can have different spelling, such as "behaviour" and "behaviour". Hence, with this information, the query string for this bibliometric analysis was set as: (TITLE-ABS ( "organi*a*ional citizenship behavi*r" ) AND DOCTYPE ( ar ) AND PUBYEAR > 1988 AND PUBYEAR < 2019 AND ( LIMIT-TO ( SRCTYPE, "j" ) ). The asterisk symbol was used in the 
query for the purpose to include both results of "organizational citizenship behaviour" and "organisational citizenship behavior". A total of 2, 713 documents was found in this query string.

The 2, 713 documents might include review papers which were irrelevant for the bibliometric analysis. Hence, an additional step was done to exclude the review papers by adding related phrases into query string, such as "review", "progress", "revisit", and "highlight". After screening the contents of the list, 265 documents were found as review articles. The EIDs (Scopus article identifier) of the 265 documents were recorded and added to the next query string for the purpose to exclude them. After excluded review papers, 2, 448 documents were found. However, these 2, 448 documents were in different languages. The author might have difficulties in understanding the articles that were not in English language, hence non-English language articles were excluded in the searching process. A total of 92 articles was found to be in other languages, therefore 2, 356 articles were obtained for this analysis. The result of searching was then analysed based on document type, country, affiliation, year, subject area, authors, and source. In order make a ranking list, the indicators of bibliometric such as h-index and total of citations were collected. The process of search strategy was illustrated in Figure 1. The detailed search strings were listed in the section of supplementary material (Table S1).

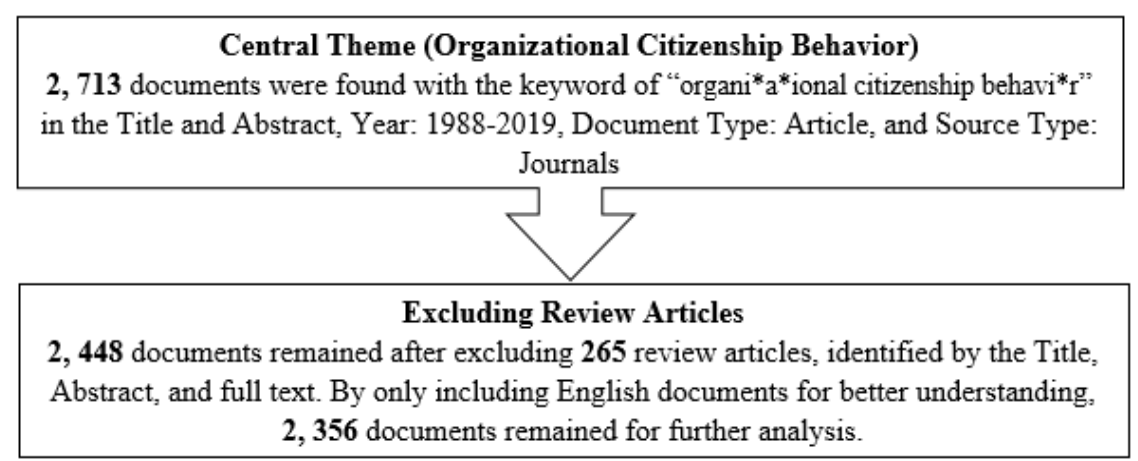

Figure 1. Process of collecting data of publications for central theme

\subsection{Bibliometric Map}

This study exported the bibliographical information of 2, 356 articles to analyse using VOSviewer version 1.6.11. VOSviewer assisted the author to visualise and build bibliometric maps which will be shown in the subsequent sections. The items in this paper that were included in VOSviewer were objects of interest such as countries of publications and author keywords. Each item might be connected with a line in VOSviewer and each line was given a strength value to illustrate the strength of the relationship between items. It is believed that stronger relationship tends to have higher strength value (Khudzari et al., 2018). There was also the link strength in the co-authorship analysis that illustrated the amount of publication between both linked countries that have co-authored. On the other hand, the link strength in keywords co-occurrence analysis showed the quantity of researches where the two linked keywords occurred simultaneously (Van Eck and Waltman, 2018).

\subsubsection{Co-authorship Analysis}

This study had included 89 countries that were affiliated with 2, 139 authors in the co-authorship analysis. The affiliated countries were clustered into nine regions, namely America, United Kingdom, Middle East, Asia, Oceania, Europe, Eurasia, Africa, and Caribbean.

\subsubsection{Analysis of Co-occurrence}

The analysis of co-occurrence included author keywords and excluded Scopus indexed keywords with a total of 171 keywords from 2, 356 articles. Before importing all the author keywords into VOSviewer, thesaurus file was created in order to avoid similar keywords from repeating. Hence, this study screened 
and grouped the synonymic keywords. For example, organisation, corporate, and company have the same meaning and they are re-labelled as 'organisation'. The minimum occurrences of author keywords were set to five in producing the output of analysis. The VOSviewer was set to visualisation mode to visualise the output in viewing the strength of link between keywords, number of occurrences, and average publications of year.

\section{Results and Discussion}

\subsection{Progress of Research Output}

There were 2, 356 research articles published in 31 years. Figure 2 shows the growth of publication. The first research in OCB was in 1988 (Dalton and Cosier, 1988) and there was no published research until 1989. From 1995 onwards, the number of publications in OCB has been increasing steadily. It is believed that the research works on this topic were active since 1995. The annual growth rate increased rapidly in 2002 when the number of publications was almost five times more than the publications in 1995. The increasing number of publications has resulted in the increased number of cumulative total publications. From 2006 to 2019, the number of publications of OCB has rapidly and significantly increased. Therefore, it is believed that the attention on OCB publications will increase in future. It is suggested that more research works should have public access for the reference of future researchers. As of 2019, only $7.7 \%$ (182 research articles) had public access for readers.

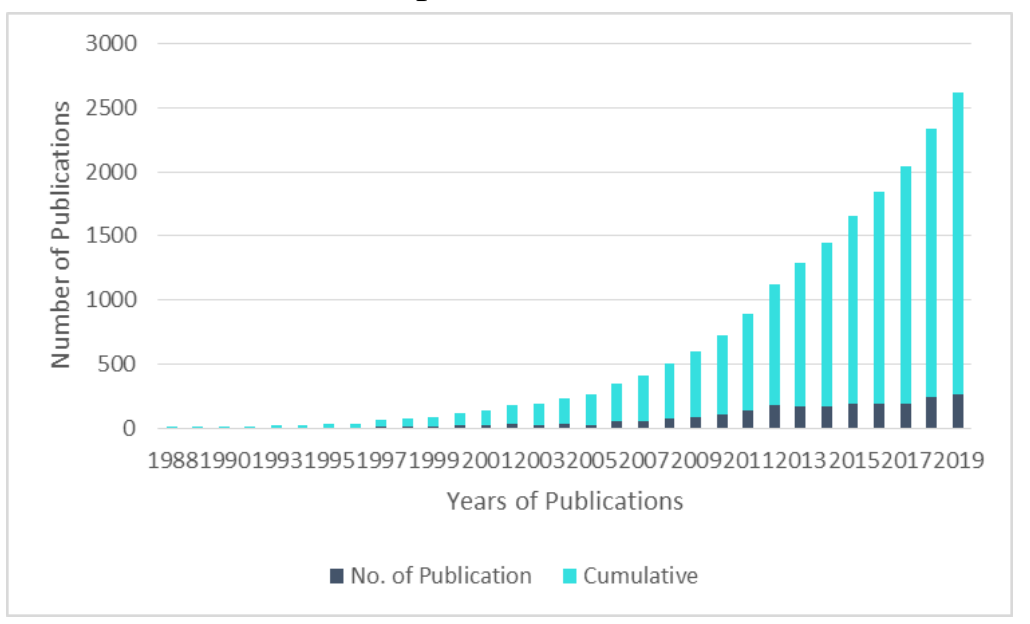

Figure 2. Annual quantity of organizational citizenship behaviour research articles in Scopus database from 1988-2019

Recently, OCB has started to receive attention from the scholars, hence increasing the number of publications. The subject area analysis indicated that the concerns of management are the main attention in OCB trend, where the followings are the top five ranking of subject area as analysed from Scopus: Business, Management, and Accounting (1, 555 articles), Social Sciences (305 articles), Psychology (823 articles), Social Sciences (773 articles), Economics, Econometrics, and Finance (229 articles), as well as Arts and Humanities (200 articles). Although major concerns are in management and social sciences field, the topic of OCB can be in multidisciplinary area as well. This can be seen when a number of publications (130 articles) was published in the area of Nursing, Medicine, and Health Professions. Besides, OCB was discussed in the field of Sciences as well, where 170 articles were published in the area of Environmental Sciences, Computer Science, as well as Agricultural and Biological Sciences. This proved that OCB is not only essential in management field, it might be important for employees in health sector and Sciences field as well.

\subsection{Top Productive Journals}

Table 1 showed that the top ten productive journals were from eight publishers. The three journals that were leading respectively from American Psychological Association (APA), Kluwer Academic 
Publishers, and Routledge. Out of the eight publishers, Elsevier and Kluwer Academic Publishers owned the greatest number of journals, where four out of ten journals are from these two publishers. The remaining four journals are published by John Wiley \& Sons Inc., SAGE Publications, Emerald Group Publishing Ltd., and Wiley-Blackwell. Majority (80\%) of the journals were in Quartile 1 (Q1), while only two journals were in Quartile 2 (Q2).

The most productive journal was Journal of Applied Psychology, where 98 journal articles were published, and covering $4.2 \%$ of total publications in OCB. Followed by Journal of Business Ethics (60, $2.5 \%$ ), International Journal of Human Resource Management (58, 2.4\%), and Journal of Organizational Behavior (52, 2.2\%). Among the ten journals, Journal of Applied Psychology has the most citation with a total of 14, 688. Journal of Organizational Behavior has the second highest citations $(5,770)$ among the ten journals. One of the papers from Journal of Vocational Behaviour has the highest citation among the ten papers $(2,540$ citations $)$.

According to the CiteScore 2018 analysis, four journals scored more than 5.0 in CiteScore. The journal with highest CiteScore was Journal of Management (10.96), while the journal with lowest CiteScore was Journal of Applied Social Psychology (1.99). CiteScore has been viewed as one of the criteria for scholars in the process selecting journals to publish their works (Khudzari et al., 2018). Hence, to assist the future scholars in looking for suitable journals, a list of top 16 CiteScore journals was attached in Table S2 (Supplementary Materials).

Table 1. Leading journals on OCB Studies

\begin{tabular}{|c|c|c|c|c|c|c|c|c|}
\hline Rank & Journal & Quartile & $\begin{array}{l}\mathbf{T P} \\
(\%)\end{array}$ & TC & $\begin{array}{l}\text { CiteScore } \\
2018\end{array}$ & $\begin{array}{l}\text { The most cited article } \\
\text { (Reference) }\end{array}$ & $\begin{array}{l}\text { Times } \\
\text { Cited }\end{array}$ & Publisher \\
\hline 1. & $\begin{array}{l}\text { Journal of } \\
\text { Applied } \\
\text { Psychology }\end{array}$ & Q1 & $\begin{array}{l}98 \\
(4.2)\end{array}$ & 14,688 & 6.86 & $\begin{array}{lr}\text { Relationship } & \text { Between } \\
\text { Organizational Justice } \\
\text { and Organizational } \\
\text { Citizenship Behaviors: } \\
\text { Dorarness } \\
\text { Perceptions Influence } \\
\text { Employee Citizenship? } \\
\text { (Moorman, 1991) }\end{array}$ & 1,594 & $\begin{array}{l}\text { American } \\
\text { Psychologi } \\
\text { cal } \\
\text { Associatio } \\
\mathrm{n}\end{array}$ \\
\hline 2. & $\begin{array}{l}\text { Journal of } \\
\text { Business } \\
\text { Ethics }\end{array}$ & Q1 & $\begin{array}{l}60 \\
(2.5)\end{array}$ & 2,305 & 4.46 & $\begin{array}{l}\text { Doing Unto Others: } \\
\text { The Reciprocity of } \\
\text { Helping Behavior in } \\
\text { Organizations (Deckop, } \\
\text { Cirka, \& Anderson, } \\
\text { 2003) }\end{array}$ & 140 & $\begin{array}{l}\text { Kluwer } \\
\text { Academic } \\
\text { Publishers }\end{array}$ \\
\hline 3. & $\begin{array}{l}\text { International } \\
\text { Journal of } \\
\text { Human } \\
\text { Resource } \\
\text { Management }\end{array}$ & $\overline{\mathrm{Q} 1}$ & $\begin{array}{l}58 \\
(2.4)\end{array}$ & 1,278 & 2.71 & $\begin{array}{lr}\text { The link } & \text { between } \\
\text { perceived human } & \\
\text { resource management } \\
\text { practices, engagement } \\
\text { and } \\
\text { behaviour: employee } \\
\text { moderated mediation } \\
\text { model (Alfes et al., } \\
\text { 2013) }\end{array}$ & 195 & Routledge \\
\hline 4. & $\begin{array}{l}\text { Journal of } \\
\text { Organizationa } \\
\text { 1 Behavior }\end{array}$ & Q1 & $\begin{array}{l}52 \\
(2.2)\end{array}$ & 5,770 & 6.59 & $\begin{array}{l}\text { Individualism - collecti } \\
\text { vism as an individual } \\
\text { difference predictor of } \\
\text { organizational } \\
\text { citizenship behaviour } \\
\text { (Moorman \& Blakely, } \\
\text { 1995) }\end{array}$ & 569 & $\begin{array}{lr}\text { John } & \text { Wiley } \\
\& \quad \text { Sons } \\
\text { Inc. }\end{array}$ \\
\hline
\end{tabular}




\begin{tabular}{|c|c|c|c|c|c|c|c|c|}
\hline 5. & $\begin{array}{l}\text { Journal of } \\
\text { Management }\end{array}$ & Q1 & $\begin{array}{l}41 \\
(1.7)\end{array}$ & 5,377 & 10.96 & $\begin{array}{l}\text { Job Satisfaction and } \\
\text { Organizational } \\
\text { Commitment } \\
\text { Predictors } \\
\text { Organizational of } \\
\text { Citizenship and In-Role } \\
\text { Behaviors (Williams \& } \\
\text { Anderson, 1991) }\end{array}$ & 1,599 & $\begin{array}{l}\text { SAGE } \\
\text { Publication } \\
\mathrm{s}\end{array}$ \\
\hline 6. & $\begin{array}{l}\text { Leadership } \\
\text { Quarterly }\end{array}$ & Q1 & $\begin{array}{l}37 \\
(1.6)\end{array}$ & 3,959 & 6.23 & $\begin{array}{l}\text { Transformational } \\
\text { leader behaviors and } \\
\text { their effects on } \\
\text { followers' trust in } \\
\text { leader, satisfaction, and } \\
\text { organizational } \\
\text { citizenship behaviors } \\
\text { (Podsakoff et al., 1990) }\end{array}$ & 2,228 & $\begin{array}{l}\text { Elsevier } \\
\text { Ltd. }\end{array}$ \\
\hline 7. & $\begin{array}{l}\text { Journal of } \\
\text { Business and } \\
\text { Psychology }\end{array}$ & Q1 & $\begin{array}{l}36 \\
(1.5)\end{array}$ & 1,160 & 3.17 & $\begin{array}{l}\text { Broken promises: } \\
\text { Equity sensitivity as a } \\
\text { moderator between } \\
\text { psychological contract } \\
\text { breach and employee } \\
\text { attitudes and behaviour } \\
\text { (Kickul \& Lester, } \\
\text { 2001) }\end{array}$ & 116 & $\begin{array}{l}\text { Kluwer } \\
\text { Academic/ } \\
\text { Plenum } \\
\text { Publishers }\end{array}$ \\
\hline 8. & $\begin{array}{l}\text { Journal of } \\
\text { Managerial } \\
\text { Psychology }\end{array}$ & Q2 & $\begin{array}{l}34 \\
(1.4)\end{array}$ & 1,983 & 2.05 & $\begin{array}{l}\text { Antecedents and } \\
\text { consequences of } \\
\text { employee engagement } \\
(\text { Saks, 2006) }\end{array}$ & 1,258 & $\begin{array}{l}\text { Emerald } \\
\text { Group } \\
\text { Publishing } \\
\text { Ltd. }\end{array}$ \\
\hline 9. & $\begin{array}{l}\text { Journal of } \\
\text { Vocational } \\
\text { Behavior }\end{array}$ & Q1 & $\begin{array}{l}29 \\
(1.2)\end{array}$ & 3,765 & 4.80 & $\begin{array}{l}\text { Affective, continuance, } \\
\text { and normative } \\
\text { commitment to the } \\
\text { organization: A meta- } \\
\text { analysis of antecedents, } \\
\text { correlates, and } \\
\text { consequences (Meyer } \\
\text { et al., 2002) }\end{array}$ & 2,540 & $\begin{array}{l}\text { Elsevier } \\
\text { Inc. }\end{array}$ \\
\hline 10. & $\begin{array}{l}\text { Journal of } \\
\text { Applied } \\
\text { Social } \\
\text { Psychology }\end{array}$ & Q2 & $\begin{array}{l}27 \\
(1.1)\end{array}$ & 796 & 1.99 & $\begin{array}{l}\text { Exchange Ideology as a } \\
\text { Moderator of Job } \\
\text { Attitudes - Organizatio } \\
\text { nal Citizenship } \\
\text { Behaviors } \\
\text { Relationships (Witt, } \\
\text { 1991) }\end{array}$ & 95 & $\begin{array}{l}\text { Wiley- } \\
\text { Blackwell }\end{array}$ \\
\hline
\end{tabular}

Note: TP= Total Publication; $T$ C = Total Citation

\subsection{Top Nations, Collaboration, and Institutions}

Figure 3 illustrated the leading nations that contributed to the development of OCB studies at the global level. About $50 \%$ of the publications were dominated by United States and China, which indicating that the both countries were the key contributors in this research topic. United States had the most publications with 847 publications, covering $40 \%$ of the publications in the global level. With 203 publications, China was ranked as the second most productive countries in OCB publication. To provide more detailed information on productive countries and institutions, a list of top 50 leading countries was attached in Table S3 (Supplementary Material).

In Figure 3, among the top 15 countries, only six countries scored more than two third (2/3) single country publications (SCP), namely Iran (90.6\%), Israel (86.3\%), India (80.8\%), Taiwan (80.5\%), 
Turkey (75.0\%), and United States (67.3\%). When SCP is high, it brings a meaning that the nations had more collaborations among the nations (Khudzari et al., 2018). While, United Kingdom had the lowest SCP $(18.6 \%)$ that only $44 / 172$ publications were associated to other organizations from 44 nations. It is believed that, by collaborating with other international institutions, it can be an effective approach to share expertise, as well as a good strategy to be ranked higher. Although Taiwan is a comparatively smaller country, $28(22 \%)$ of its published works were worldwide collaborations which associated to 18 countries, consequently it was ranked as top $6^{\text {th }}$ leading nation. In addition, there are five institutions were ranked as the top 150 best universities in World University Rankings 2019 (THE, 2019), namely University of Toronto $\left(21^{\text {st }}\right)$, Seoul National University $\left(63^{\text {rd }}\right)$, Erasmus University Rotterdam $\left(70^{\text {th }}\right)$, Monash University $\left(84^{\text {th }}\right)$ and Michigan State University $\left(93^{\text {rd }}\right)$. From this, it can be seen that OCB has been receiving attention from the top universities in international level.

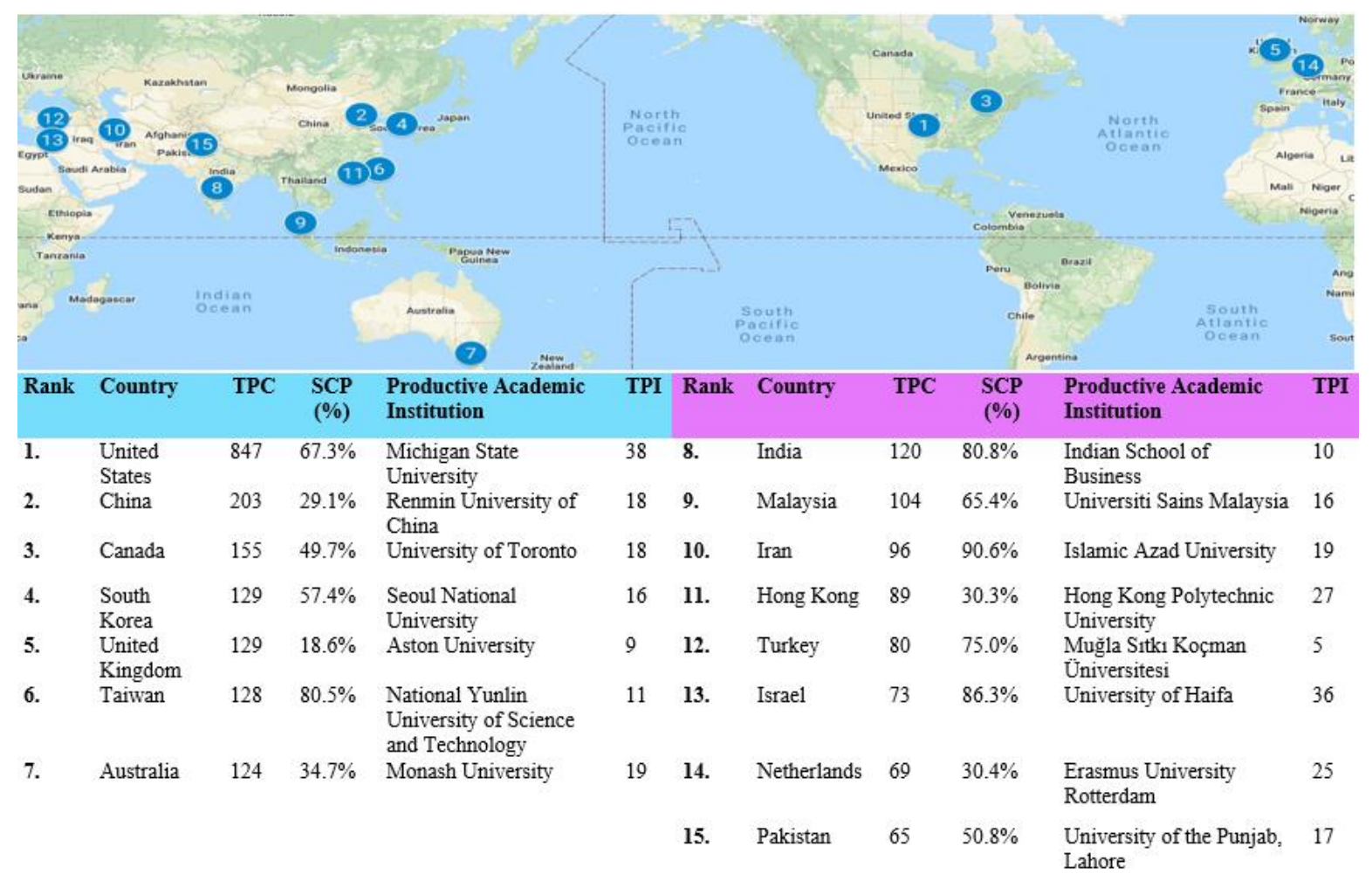

Note: TPC: total publications of the particular country; SCP: single-country publications; TPI: total publications of the particular organization

\section{Figure 3. Leading nations and institutes in OCB studies}

Furthermore, Figure 4 illustrated the distribution of the countries. According to Khudzari et al. (2018), the stronger the linkage between two countries, the locations of both countries will be closer in VOSviewer. While, the stronger the linkage, the line showed in VOSviewer will be thicker. In OCB area, the region that had highest publication rate was from America (42), followed by Asia (26), Europe (24), Middle East (14), Africa (13), United Kingdom (4), Eurasia (3), Caribbean (2), and Oceania (2). The co-authorship analysis indicated that United States was the country that had the most affiliations (50 links, 388 co-authorship), then followed by United Kingdom (44 links, 172 co-authorship), China (43 links, 232 co-authorship), Australia (42 links, 146 co-authorship), Germany (38 links, 73 co-authorship), and others. The analysis found that two fifth $(2 / 5)$ of the countries had less than ten international collaborative publications. In addition, there were researchers from nine countries were not affiliated with any countries in publishing OCB articles, namely Costa Rica, Croatia, Iraq, Malta, Morocco, Puerto Rico, Sri Lanka, Syria, and Uganda. Few factors could be the contributors to the trend of international collaboration, such as number of international students, diverse research working colleagues, sufficiency of research funding, as well as supportive climate in research institution. For instance, from the Scopus 
database, it indicated that National Natural Science Foundation of China is the top funding sponsor, hence resulting that China was the top two productive country in publishing OCB articles.

\& VOSviewer

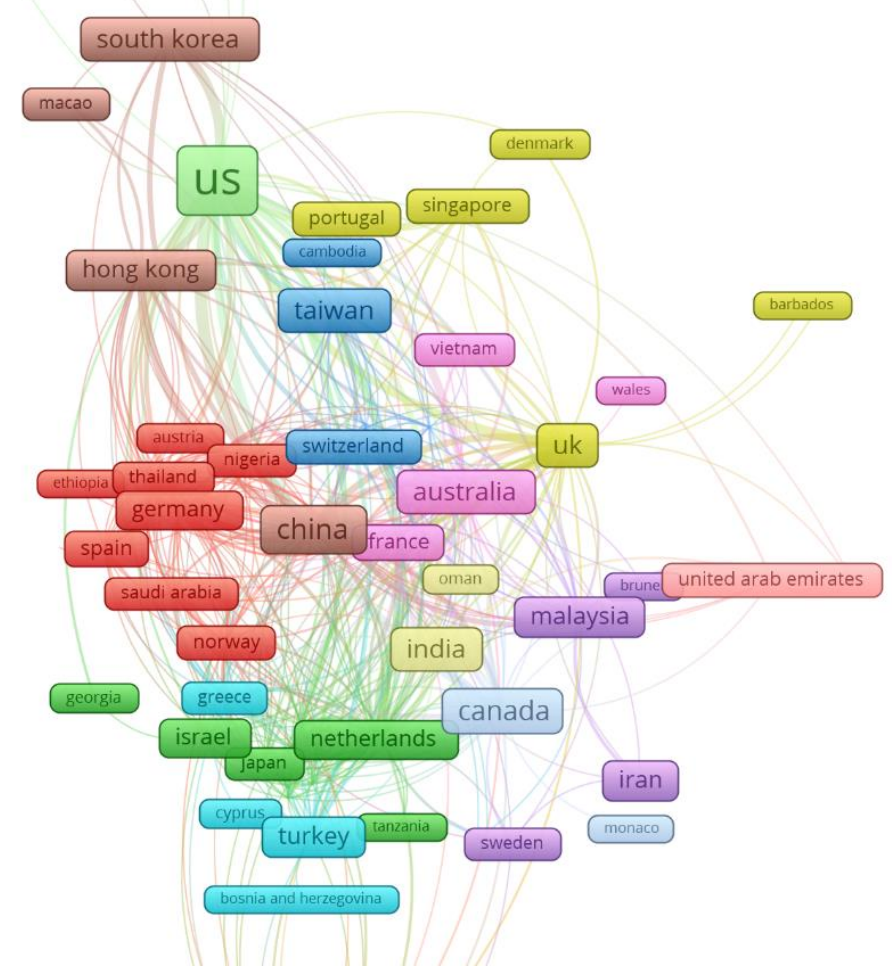

Figure 4. The bibliometric map of co-authorships (http://bit.ly/OCBCountryGJL)

\subsection{Top Scholars}

The top 15 productive authors in the research area of OCB are listed in Table 2, whom currently attached to seven countries as follows: United States (8), Canada (1), Israel (2), Australia (1), UK (1), Pakistan (1), and India (1). The leading authors' first publication ranged between the years of 1990 to 2011, in which more than half (10) of them were first author, and five of them were second author. As shown in the column of affiliations, it can be seen that OCB is often discussed in the field of business and management, only minority of the authors were from the fields of Psychology, Education, and Political Science.

The top three leading authors were from United States. Bachrach, D.G. was the first leading author from University of Alabama, with a record of 15 publications since 2000, 666 times of citations, and with 13 h-index. Followed by Bolino, M.C. from The University of Oklahoma, a total of 15 publications (19992019), 12 h-index, as well as higher number of citations than the first leading author (2, 209). Four authors (5th, 6th, 10th and 12th) were affiliated to the same university, which are University of Haifa (5th and 6th) and Michigan State University (10th and 12th). It was discovered that the trend of OCB has been gradually increased since 2000, where Bachrach, D.G.'s article was the first published in the same year. Although these are top 15 productive and leading authors in OCB publications, it should be noted that their names are not necessarily appeared in Table 1, under the column of most cited articles. Their names would only be found in Table 1 and Table 2 if they have published actively, such as the author Podsakoff, P.M. 
Table 2. The top 15 productive scholars in OCB studies

\begin{tabular}{|c|c|c|c|c|c|c|c|c|}
\hline Rank & Author & $\begin{array}{l}\text { ID of Author } \\
\text { in Scopus }\end{array}$ & $\begin{array}{l}\text { First } \\
\text { publication } \\
\text { year* }\end{array}$ & $\begin{array}{l}\text { TT } \\
\text { Pub }\end{array}$ & $\begin{array}{l}\text { h- } \\
\text { index }\end{array}$ & TTCtn & $\begin{array}{l}\text { Current } \\
\text { Affiliation }\end{array}$ & Country \\
\hline 1. & $\begin{array}{l}\text { Bachrach, } \\
\text { D.G. }\end{array}$ & 6701519822 & $2000^{\mathrm{a}}$ & 15 & 13 & 666 & $\begin{array}{l}\text { University } \\
\text { Alabama, } \\
\text { Department } \\
\text { Management } \\
\text { Marketing }\end{array}$ & US \\
\hline 2. & $\begin{array}{l}\text { Bolino, } \\
\text { M.C. }\end{array}$ & 6701369361 & $1999^{\mathrm{a}}$ & 15 & 12 & 2,209 & $\begin{array}{l}\text { The University of } \\
\text { Oklahoma, Division } \\
\text { of Management \& } \\
\text { International } \\
\text { Business }\end{array}$ & US \\
\hline 3. & $\begin{array}{l}\text { Chiaburu, } \\
\text { D.S. }\end{array}$ & 16678220400 & $2006^{\mathrm{a}}$ & 14 & 8 & 493 & $\begin{array}{l}\text { Lehigh University, } \\
\text { Department of } \\
\text { Management }\end{array}$ & US \\
\hline 4. & Paillé, P. & 23995349700 & $2009^{a}$ & 14 & 8 & 483 & $\begin{array}{l}\text { Université } \\
\text { Lepartment } \\
\text { Management }\end{array}$ & Canada \\
\hline 5. & $\begin{array}{l}\text { Somech, } \\
\text { A. }\end{array}$ & 6701826962 & $2002^{a}$ & 14 & 10 & 618 & $\begin{array}{l}\text { University of Haifa, } \\
\text { Educational } \\
\text { Leadership \& } \\
\text { Policy Department }\end{array}$ & Israel \\
\hline 6. & Cohen, A. & 7404781570 & $2000^{\mathrm{a}}$ & 12 & 10 & 364 & $\begin{array}{l}\text { University of Haifa, } \\
\text { Department of } \\
\text { Political Science }\end{array}$ & Israel \\
\hline 7. & $\begin{array}{l}\text { Podsakoff, } \\
\text { P.M. }\end{array}$ & 6603818084 & $1990^{\mathrm{b}}$ & 11 & 11 & 5,288 & $\begin{array}{l}\text { University of } \\
\text { Florida, Department } \\
\text { of Management }\end{array}$ & US \\
\hline 8. & $\begin{array}{l}\text { Spector, } \\
\text { P.E. }\end{array}$ & 7006644298 & $2001^{b}$ & 11 & 8 & 2,543 & $\begin{array}{l}\text { University of South } \\
\text { Florida, Tampa, } \\
\text { Department } \\
\text { Psychology }\end{array}$ & US \\
\hline 9. & $\begin{array}{l}\text { Johnson, } \\
\text { R.E. }\end{array}$ & 12647656600 & $2006^{\mathrm{a}}$ & 10 & 9 & 474 & $\begin{array}{lr}\text { Michigan } & \text { State } \\
\text { University, } & \text { East } \\
\text { Lansing, } & \\
\begin{array}{l}\text { Department } \\
\text { Management }\end{array} & \text { of }\end{array}$ & US \\
\hline 10. & $\begin{array}{l}\text { Lester, } \\
\text { S.W. }\end{array}$ & 7005311026 & $2001^{\mathrm{b}}$ & 10 & 7 & 839 & $\begin{array}{l}\text { University of } \\
\text { Wisconsin-Eau } \\
\text { Claire, Department } \\
\text { of Management and } \\
\text { Marketing }\end{array}$ & US \\
\hline 11. & $\begin{array}{l}\text { Restubog, } \\
\text { S.L.D. }\end{array}$ & 13905925700 & $2007^{a}$ & 10 & 7 & 360 & $\begin{array}{l}\text { Australian National } \\
\text { University, } \\
\text { Canberra, } \\
\text { Department of } \\
\text { Psychology }\end{array}$ & Australia \\
\hline 12. & $\begin{array}{l}\text { Van Dyne, } \\
\text { L. }\end{array}$ & 6603945507 & $2001^{\mathrm{b}}$ & 10 & 10 & 1,349 & $\begin{array}{lr}\text { Michigan } & \text { State } \\
\text { University, } & \text { East } \\
\text { Lansing, } & \\
\begin{array}{l}\text { Department } \\
\text { Management }\end{array} & \text { of }\end{array}$ & US \\
\hline 13. & $\begin{array}{l}\text { De } \\
\text { Cremer, D. }\end{array}$ & 7006810104 & $2005^{\mathrm{a}}$ & 9 & 8 & 329 & 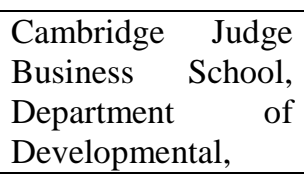 & UK \\
\hline
\end{tabular}




\begin{tabular}{|l|l|l|l|l|l|l|l|l|}
\hline & & & & & & & $\begin{array}{l}\text { Personal, and } \\
\text { Social Psychology }\end{array}$ \\
\hline 14. & Islam, T. & 53863375600 & $2011^{\mathrm{b}}$ & 9 & 5 & 46 & $\begin{array}{l}\text { University of the } \\
\text { Punjab, Lahore, } \\
\text { Institute of } \\
\text { Business } \\
\text { Administration }\end{array}$ & \\
\hline 15. & $\begin{array}{l}\text { Kamdar, } \\
\text { D. }\end{array}$ & 57194934282 & $2006^{\mathrm{a}}$ & 9 & 9 & 872 & $\begin{array}{l}\text { Indian School of India } \\
\text { Business, } \\
\text { Department of } \\
\text { Organization } \\
\text { Behavior }\end{array}$ \\
\hline
\end{tabular}

Note $^{*}=\mathrm{a}$ : First Author, b: Second Author, c: Third Author and above; TTPub=Total Publication; TTCtn=Total Citation

\subsection{Author Keywords}

Before creating a thesaurus file, this study recorded 1001 author keywords was recorded, where $17.0 \%$ (170) were used only once, 32.2\% (322) were used twice, $16.7 \%$ (167) were used thrice, $8.1 \%$ (81) were used for four times, while $26.0 \%$ (260) were used for more than five times. The author keywords were re-labelled by creating a thesaurus file before processing the analysis. There was a total of 171 author keywords yielded from the analysis (minimum five occurrences).

\subsubsection{Concept and Terminology}

The result of author keywords co-occurrences analysis indicated that 'OCB' was the most regularly used keywords in the past studies, where there were 1385 occurrences and 170 links to other keywords as illustrated in Figure 5. Two types of OCB were mentioned in author keywords, which were serviceoriented OCB (9 occurrences, 11 links), and OCB Environmental (OCBE) (8 occurrences, 10 links). In addition to that, several keywords were used in conceptualising the OCB, for example, 'citizenship' (26 occurrences), and 'prosocial behaviour' (6 occurrences), 'courtesy' (8 occurrences), sportsmanship (14 occurrences), conscientiousness (22 occurrences), altruism (21 occurrences), helping (26 occurrences), and civic virtue (14 occurrences). The concept of OCB was connected to the few theories, such as 'person-organization fit' (22 occurrences), 'social exchange' (78 occurrences), and 'social identity' (17 occurrences), 'conservation of resources theory' (9 occurrences), 'self-determination theory' (8 occurrences), and 'affective events theory' ( 5 occurrences). It can be seen that social exchange theory had the most occurrences, where the scholars believed that, reciprocity (5 occurrences, 11 links) could happen when employees are treated well by organizations, the employees will reciprocate by exhibiting OCB in organizations (Liaquat \& Mehmood, 2017). One of the most cited papers in Table 1 was related to 'reciprocity', which was "Doing unto Others: The Reciprocity of Helping Behavior in Organizations" by Deckop, Cirka, and Anderson (2003).

\subsubsection{Topic of Interest}

Organizational citizenship behaviour (OCB) has been gaining attention in recent years, where it was recognized as one of the contributors in enhancing the sustainability of organizations (Wang et al., 2018). Among 171 author keywords, 'commitment' has the most occurrences (206 occurrences, 99 links), followed by 'job satisfaction' (183 occurrences, 102 links). The analysis results are consistent with the findings in Table 1, where two most cited papers mentioned about 'commitment' as well as 'job satisfaction' in examining OCB. The first paper discussed about "Job Satisfaction and Organizational Commitment as Predictors of Organizational Citizenship and In-Role Behaviors" by Williams and Anderson (1991), while the second paper discussed about "Affective, continuance, and normative commitment to the organization: A meta-analysis of antecedents, correlates, and consequences" by Meyer et al. (2002). The branch of 'commitment' that is, 'affective commitment' (64 occurrence, 49 links) was also frequently mentioned among the scholars in examining OCB. 
The bibliometric analysis result of author keywords indicated that, majority of the top ten author keywords were the antecedents of OCB, namely 'organizational justice' (166 occurrences, 82 links), 'perceived organizational support' (100 occurrences, 69 links), 'job engagement' (83 occurrences, 74 links), and 'organizational trust' (77 occurrences, 64 links). Among the top ten, only 'turnover intention' (66 occurrences, 47 links) was the most discussed consequence of OCB. The analysis results brought a meaning that, most of the past studies discussed antecedents of OCB, as compared to the consequences of OCB. The high frequency of the discussion in 'job engagement' could be seen from Table 1, where two most cited papers that were discussed by Saks (2006) and Alfes et al. (2013) were about employees' 'engagement'. Besides, the topic of 'organizational justice' was also one of the frequent discussed topic in OCB studies, where Moorman's (1991) "Relationship between Organizational Justice and Organizational Citizenship Behaviors: Do Fairness Perceptions Influence Employee Citizenship?" was one of the most cited papers, as indicated in Table 1.

Other than organizational behaviour variables, OCB was also concerned in psychology field. There were nine author keywords that related to psychology field. 'Psychological contract' had received the most attention (52 occurrences, 48 links). This is consistent with the result that showed in Table 1, where there was one 'psychological contract' related articles listed as the most cited papers, which was "Broken promises: Equity sensitivity as a moderator between psychological contract breach and employee attitudes and behaviour" (Kickul \& Lester, 2001). Followed by author keyword 'emotional intelligence' (41 occurrences, 39 links), where it is believed that emotion (10 occurrences, 19 links) is one of the key elements in exhibiting OCB among employees (Ilies et al., 2013). 'Emotional intelligence' had become the recent trend in OCB research (Average Publication Year: 2014.976). Besides these keywords, other author keywords that related to psychology field were also mentioned, such as 'emotional exhaustion' (18 occurrences, 24 links), 'emotional labor' (18 occurrences, 20 links), and 'psychological capital' (14 occurrences, 16 links).

Furthermore, OCB was also related to seven types of leadership in organizations, namely transformational leadership, ethical leadership, servant leadership, authentic leadership, spiritual leadership, charismatic leadership, and transactional leadership. Among these seven leadership styles, transformational leadership had the most co-occurrences in OCB research (69 occurrence, 58 links), followed by ethical leadership (45 occurrences, 39 links), and servant leadership (25 occurrences, 26 links). Besides these seven types of leadership, it is believed that other types of leadership were discussed by the scholars because the general term of 'leadership' had high occurrences in OCB research (80 occurrences, 77 links). These leadership styles could be connected because it was believed that transformational leadership could enhance the level of OCB among employees (López-Domínguez et al., 2013). The high frequency of discussion in transformational leadership could be seen in Table 1, where one of the most cited paper by Podsakoff et al. (1990) was about "Transformational leader behaviors and their effects on followers' trust in leader, satisfaction, and organizational citizenship behaviors".

Among the author keywords, a total of 12 country names were found in the analysis, where this probably be due to most of the authors discussed the OCB of the 12 countries. The country that had the most occurrences was China (33 occurrences, 33 links). According to Chin (2015), OCB has been widely discussed because they believed that OCB could boost up harmonious working environment, where China culture emphasizes on harmonious relationship. Besides, due to the inherited complexity and uncertainty in China economy, voluntary positive behaviour (OCB) is highly needed in an organization to help each other when problems happened (Zhang, Bai, Wang, 2014). Hence, it could be justified that 'China' has the most occurrences among the author keywords. It was followed by India (18 occurrences, 34 links), Malaysia (15 occurrences, 21 links), and Pakistan (12 occurrences, 24 links). 
From this analysis result, it could be seen that Asia countries, which are collectivists, emphasized the occurrence of OCB in organizations in order to maintain good relationship. The culture of country in affecting OCB had been discussed, where one of the most cited paper by Moorman and Blakely (1995) was about "Individualism-collectivism as an individual difference predictor of organizational citizenship behaviour", as indicated in Table 1.

Lastly, based on the analysis of author keywords co-occurrences, it is suggested that future studies should conduct more research on the relationship between corporate social responsibility (CSR) and OCB in organizations. This is because CSR (31 occurrences, 35 links) has become one of the recent author keywords in the area of OCB (Average Publication Year: 2016.839). The relationship between CSR and OCB was frequently discussed through two theories, namely social identity theory (17 occurrences) and social exchange theory (78 occurrences). Future studies could adopt the relevant theory to examine the impact of CSR on OCB. This is because it was believed that the action of CSR from organization could bring positive impression to employees, which in turn the employees will reciprocate by showing OCB to the organizations (Kim et al., 2017).

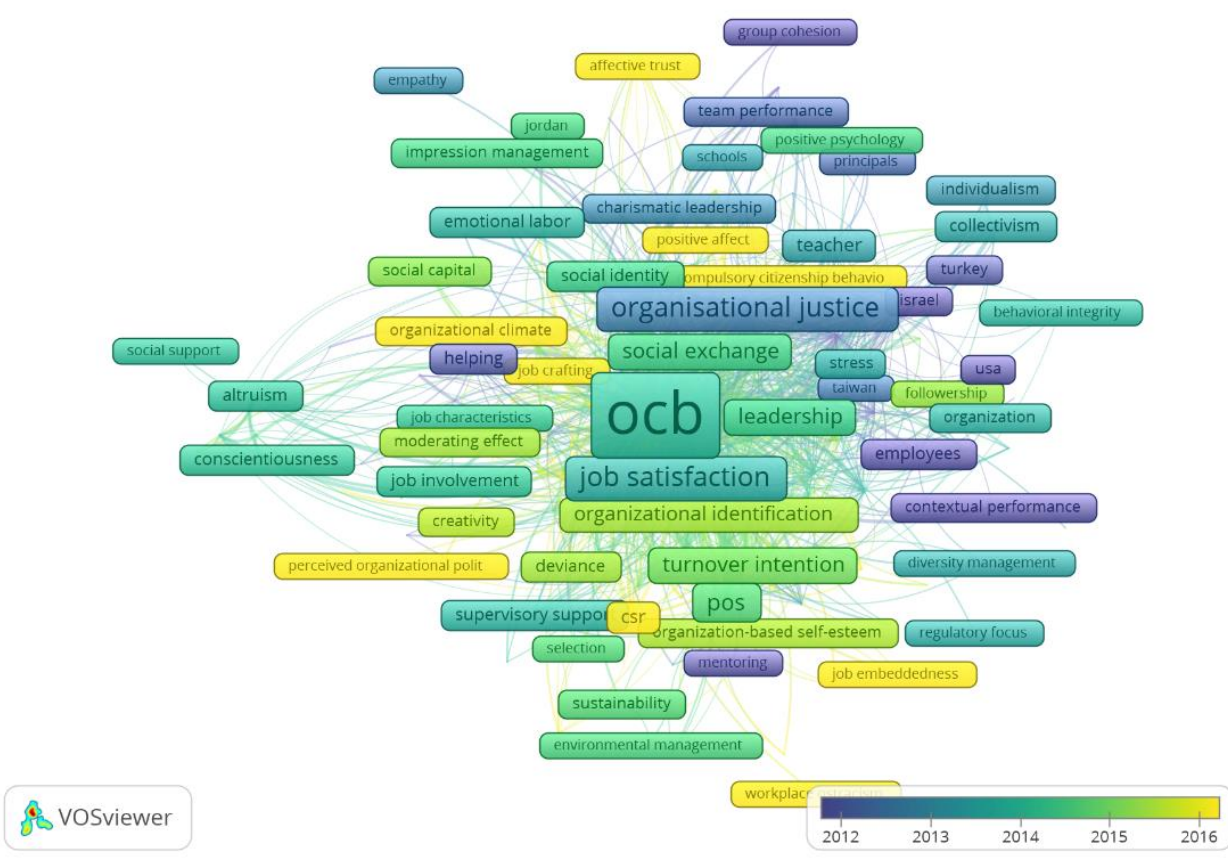

Figure 5. The bibliometric map of author keywords (Minimum occurrences: 5) (http://bit.ly/OCBKeywordsGJL)

\subsection{Limitations of Study}

This study has restricted the search for 'OCB' to the titles and abstracts. This approach might miss out selecting articles on OCB in Scopus database. It is believed that some authors might not include the keywords of 'OCB' in their studies and opted for 'extra-role performance' in explaining the extra positive behaviour among employees. Future researchers are recommended to compare the studies on 'OCB' using various databases, for example to combine Scopus and WOS. Web of Sciences shows the most 'hot paper' in their system compared to Scopus. By combining multiple databases, the bibliometric analysis can obtain more comprehensive results. Furthermore, this study did not include all languages OCB research articles, hence future studies are recommended to include all languages research articles to provide comprehensive results. 


\section{Conclusion}

The discussion and analysis explained an outline of organizational citizenship behaviour growth based on 2, 356 related studies in Scopus database. Since the year 2000 till current year, the growth of OCB has been increasing rapidly as OCB is recognized as one of the contributors of performance in organizations. The analysis indicated that the United States and China were the leading countries in OCB research area. The United States was also the most affiliated country in this research area. Other countries such as Sri Lanka and Morocco are recommended to have international collaboration with leading affiliated countries to broaden their research scopes. OCB was active in the management and business area. It was discovered that 'Organizational Citizenship Behaviour Environment' (OCBE) was new area in examining OCB. The OCBE area has the potential to become hot topic in future because because OCBE could promote the sustainability of organizations, which is one of the hot issue in this era.

\section{References}

Aghaei Chadegani, A., Salehi, H., Yunus, M., Farhadi, H., Fooladi, M., Farhadi, M., \& Ale Ebrahim, N. (2013). A comparison between two main academic literature collections: Web of Science and Scopus databases. Asian Social Science, 9(5), 18-26.

Alfes, K., Shantz, A. D., Truss, C., \& Soane, E. C. (2013). The link between perceived human resource management practices, engagement and employee behaviour: a moderated mediation model. The international journal of human resource management, 24(2), 330-351.

Chin, T. (2015). Harmony and organizational citizenship behavior in Chinese organizations. The International Journal of Human Resource Management, 26(8), 1110-1129.

Cobo, M. J., López-Herrera, A. G., Herrera-Viedma, E., \& Herrera, F. (2011). Science mapping software tools: Review, analysis, and cooperative study among tools. Journal of the American Society for Information Science and Technology, 62(7), 1382-1402.

Dalton, D. R., \& Cosier, R. A. (1988). Psychometric properties of the organizational citizenship behavior scale. Educational and Psychological Measurement, 48(2), 479-482.

Deckop, J. R., Cirka, C. C., \& Andersson, L. M. (2003). Doing unto others: The reciprocity of helping behavior in organizations. Journal of Business Ethics, 47(2), 101-113.

Ilies, R., Peng, A. C., Savani, K., \& Dimotakis, N. (2013). Guilty and helpful: An emotion-based reparatory model of voluntary work behavior. Journal of Applied Psychology, 98(6), 1051.

Khudzari, J. M., Kurian, J., Tartakovsky, B., \& Raghavan, G. V. (2018). Bibliometric analysis of global research trends on microbial fuel cells using Scopus database. Biochemical engineering journal, 136, 51-60.

Kickul, J., \& Lester, S. W. (2001). Broken promises: Equity sensitivity as a moderator between psychological contract breach and employee attitudes and behavior. Journal of business and psychology, 16(2), 191-217.

Kim, H. L., Rhou, Y., Uysal, M., \& Kwon, N. (2017). An examination of the links between corporate social responsibility (CSR) and its internal consequences. International Journal of Hospitality Management, 61, 26-34.

Liaquat, M., \& Mehmood, K. (2017). Organization Citizenship Behavior: Notion of Social Exchange Theory. Journal of Business and Social Review in Emerging Economies, 3(2), 209-216.

López-Domínguez, M., Enache, M., Sallan, J. M., \& Simo, P. (2013). Transformational leadership as an antecedent of change-oriented organizational citizenship behavior. Journal of Business Research, 66(10), 2147-2152.

Meyer, J. P., Stanley, D. J., Herscovitch, L., \& Topolnytsky, L. (2002). Affective, continuance, and normative commitment to the organization: A meta-analysis of antecedents, correlates, and consequences. Journal of vocational behavior, 61(1), 20-52.

Moorman, R. H. (1991). Relationship between organizational justice and organizational citizenship behaviors: Do fairness perceptions influence employee citizenship?. Journal of applied psychology, 76(6), 845.Deckop, Cirka, \& Anderson, 2003 
Moorman, R. H., \& Blakely, G. L. (1995). Individualism-collectivism as an individual difference predictor of organizational citizenship behavior. Journal of organizational behavior, 16(2), 127142.

Organ, D.W. (1988). Organizational Citizenship Behavior: The Good Soldier Syndrome; Lexington Books: Lexington, USA.

Podsakoff, P. M., MacKenzie, S. B., Moorman, R. H., \& Fetter, R. (1990). Transformational leader behaviors and their effects on followers' trust in leader, satisfaction, and organizational citizenship behaviors. The leadership quarterly, 1(2), 107-142. Kickul \& Lester, 2001

Romeo Delgado, M., Yepes i Baldó, M., Bòria Reverter, S., \& Merigó Lindahl, J. M. (2017). Twentyfive years of research on work and organizational psychology: A bibliometric perspective. Anuario de Psicología, 2017, vol. 47, p. 32-44.

Saks, A. M. (2006). Antecedents and consequences of employee engagement. Journal of managerial psychology, 21(7), 600-619.

Van Eck, N. J. \& Waltman, L. (2018). Manual for VOSviewer Version 1.6.11.

Wang, T., He, Q., Lu, Y., \& Yang, D. (2018). How Does Organizational Citizenship Behavior (OCB) Affect the performance of megaprojects? Insights from a System Dynamic Simulation. Sustainability, 10(6), 1708.

Williams, L. J., \& Anderson, S. E. (1991). Job satisfaction and organizational commitment as predictors of organizational citizenship and in-role behaviors. Journal of management, 17(3), 601-617.

Witt, L. A. (1991). Exchange ideology as a moderator of job attitudes-organizational citizenship behaviors relationships. Journal of Applied Social Psychology, 21(18), 1490-1501.

Yaylaci, A. F. (2016). An Analysis of Studies on Organizational Citizenship Behaviors in Turkey: 20002015. Journal of Education and Training Studies, 4(8), 99-115.

Zhang, G., Bai, Y. T., \& Wang, L. (2014). Leader integrity and organizational citizenship behaviour in China. Management and Organization Review, 10(2), 299-319.

Zupic, I., \& Čater, T. (2015). Bibliometric methods in management and organization. Organizational Research Methods, 18(3), 429-472.

\section{SUPPLEMENTARY MATERIALS}

\section{Research article:}

A Global Research Trend on Organizational Citizenship Behaviour: A Bibliometric Analysis

\section{Supplementary information:}

Table S1: Search strategies and query strings

Table S2: The leading CiteScore journals in Organizational Citizenship Behaviour studies (Minimum 20 research articles)

Table S3: The top 50 most productive institutions in Organizational Citizenship Behaviour Research

\section{Authors:}

Jen Ling Gan ${ }^{1}$, Halimah Mohd Yusof ${ }^{2}$

\section{Affiliations:}

${ }^{1}$ Azman Hashim International Business School, Universiti Teknologi Malaysia, 81310 Skudai, Johor.

${ }^{2}$ School of Human Resource Development and Psycholgy, Faculty of Social Sciences and Humanities, Universiti Teknologi Malaysia, 81310 Skudai, Johor.

\section{Corresponding Author:}

ganjenling@gmail.com 
Table S1: Search strategies and query strings

\begin{tabular}{|c|c|c|c|}
\hline Items & Theme & Search for: & Query Strings \\
\hline i & Central & OCB research articles & $\begin{array}{l}\text { (TITLE-ABS-KEY ( "organi*a*ional citizenship behavi*r" ) } \\
\text { AND DOCTYPE ( ar ) AND PUBYEAR > } 1983 \text { AND } \\
\text { PUBYEAR < } 2020 \text { AND ( LIMIT-TO ( SRCTYPE, "j" ) } \\
\text { )YEAR > 1974 AND PUBYEAR < } 2018 \text { AND (LIMIT-TO } \\
(\text { SRCTYPE, "j")) }\end{array}$ \\
\hline ii. & Central & Review articles in (i) & $\begin{array}{l}\text { (TITLE-ABS ("organi*a*ional citizenship behavi*r ")) AND } \\
\text { (TITLE ("recent" OR progress OR review OR critical OR } \\
\text { revisit OR advance OR development OR highlight OR } \\
\text { perspective OR prospect OR trends OR bibliometric OR } \\
\text { scientometric) OR (ABS (progress OR review OR } \\
\text { bibliometric OR scientometric )) ) }\end{array}$ \\
\hline iii & Central & $\begin{array}{l}\text { OCB research without } \\
\text { review articles and } \\
\text { excluding non-English } \\
\text { languages }\end{array}$ & $\begin{array}{l}\text { (TITLE-ABS ("organi*a*ional citizenship behavi*r ")) AND } \\
\text { DOCTYPE (ar) AND PUB YEAR > } 1991 \text { AND PUBYEAR < } \\
2020 \text { AND NOT EID (insert EID of review articles here*) } \\
\text { AND (LIMIT-TO (SRCTYPE, "j")) AND ( EXCLUDE ( } \\
\text { LANGUAGE,"Spanish" ) OR EXCLUDE ( } \\
\text { LANGUAGE,"German" ) OR EXCLUDE ( } \\
\text { LANGUAGE,"Chinese" ) OR EXCLUDE ( } \\
\text { LANGUAGE,"Turkish" ) OR EXCLUDE ( } \\
\text { LANGUAGE,"French" ) OR EXCLUDE ( } \\
\text { LANGUAGE,"Korean" ) OR EXCLUDE ( } \\
\text { LANGUAGE,"Croatian" ) OR EXCLUDE ( } \\
\text { LANGUAGE,"Persian" ) OR EXCLUDE ( } \\
\text { LANGUAGE,"Russian" ) OR EXCLUDE ( } \\
\text { LANGUAGE,"Ukrainian" ) OR EXCLUDE ( } \\
\text { LANGUAGE,"Bosnian" ) OR EXCLUDE ( } \\
\text { LANGUAGE,"Czech" ) OR EXCLUDE ( } \\
\text { LANGUAGE,"Dutch" ) OR EXCLUDE ( } \\
\text { LANGUAGE,"Italian" ) OR EXCLUDE ( } \\
\text { LANGUAGE,"Japanese" ) OR EXCLUDE ( } \\
\text { LANGUAGE,"Arabic" ) OR EXCLUDE ( } \\
\text { LANGUAGE,"Indonesian" ) OR EXCLUDE ( } \\
\text { LANGUAGE,"Portuguese" ) ) ) }\end{array}$ \\
\hline
\end{tabular}

Table S2: The leading CiteScore journals in Organizational Citizenship Behaviour studies (With minimum requirement of twenty publications and above)

\begin{tabular}{|c|c|c|c|c|c|}
\hline Rank & $\begin{array}{l}\text { Name of } \\
\text { Journal }\end{array}$ & $\begin{array}{l}\text { CiteScore } \\
\text { in } 2018\end{array}$ & Link of Journal & $\begin{array}{l}\text { Organization } \\
\text { of Publishing }\end{array}$ & $\begin{array}{l}\text { Amount of } \\
\text { Publication }\end{array}$ \\
\hline 1. & $\begin{array}{l}\text { Journal Of } \\
\text { Management }\end{array}$ & 10.96 & $\begin{array}{l}\text { https://journals.sagepub.com/h } \\
\text { ome/jom }\end{array}$ & $\begin{array}{l}\text { SAGE } \\
\text { Publications }\end{array}$ & 41 \\
\hline 2. & $\begin{array}{l}\text { Journal Of } \\
\text { Applied } \\
\text { Psychology }\end{array}$ & 6.86 & $\begin{array}{l}\text { https://www.apa.org/pubs/jour } \\
\text { nals/apl/ }\end{array}$ & $\begin{array}{l}\text { American } \\
\text { Psychological } \\
\text { Association }\end{array}$ & 98 \\
\hline 3. & $\begin{array}{l}\text { Journal Of } \\
\text { Organizational } \\
\text { Behavior }\end{array}$ & 6.59 & $\begin{array}{l}\text { https://onlinelibrary.wiley.com } \\
\text { /journal/10991379 }\end{array}$ & $\begin{array}{l}\text { John Wiley \& } \\
\text { Sons Inc. }\end{array}$ & 52 \\
\hline 4. & $\begin{array}{l}\text { Leadership } \\
\text { Quarterly }\end{array}$ & 6.23 & $\begin{array}{l}\text { https://www.sciencedirect.com } \\
\text { /journal/the-leadership- } \\
\text { quarterly }\end{array}$ & Elsevier Ltd. & 37 \\
\hline 5. & $\begin{array}{l}\text { International } \\
\text { Journal Of } \\
\text { Hospitality } \\
\text { Management }\end{array}$ & 5.56 & $\begin{array}{l}\text { https://www.journals.elsevier. } \\
\text { com/international-journal-of- } \\
\text { hospitality-management }\end{array}$ & Elsevier & 24 \\
\hline 6. & $\begin{array}{l}\text { Journal Of } \\
\text { Business } \\
\text { Research }\end{array}$ & 5.32 & $\begin{array}{l}\text { https://www.journals.elsevier. } \\
\text { com/journal-of-business- } \\
\text { research }\end{array}$ & Elsevier & 22 \\
\hline
\end{tabular}




\begin{tabular}{|c|c|c|c|c|c|}
\hline 7. & $\begin{array}{l}\text { Journal Of } \\
\text { Vocational } \\
\text { Behavior }\end{array}$ & 4.8 & $\begin{array}{l}\text { https://www.journals.elsevier. } \\
\text { com/journal-of-vocational- } \\
\text { behavior }\end{array}$ & Elsevier Inc. & 29 \\
\hline 8. & $\begin{array}{l}\text { Journal Of } \\
\text { Business Ethics }\end{array}$ & 4.46 & $\begin{array}{l}\text { https://www.springer.com/phil } \\
\text { osophy/ethics+and+moral+phi } \\
\text { losophy/journal/10551?cm_m } \\
\text { mc=sgw-_-ps-_-journal-_- } \\
\text { 10551 }\end{array}$ & $\begin{array}{l}\text { Kluwer } \\
\text { Academic } \\
\text { Publishers }\end{array}$ & 60 \\
\hline 9. & $\begin{array}{l}\text { Journal Of } \\
\text { Occupational } \\
\text { And } \\
\text { Organizational } \\
\text { Psychology } \\
\end{array}$ & 4.07 & $\begin{array}{l}\text { https://onlinelibrary.wiley.com } \\
\text { /journal/20448325 }\end{array}$ & $\begin{array}{l}\text { Wiley- } \\
\text { Blackwell }\end{array}$ & 24 \\
\hline 10. & $\begin{array}{l}\text { European } \\
\text { Journal Of } \\
\text { Work And } \\
\text { Organizational } \\
\text { Psychology } \\
\end{array}$ & 3.61 & $\begin{array}{l}\text { https://www.tandfonline.com/t } \\
\text { oc/pewo20/current }\end{array}$ & $\begin{array}{l}\text { Taylor \& } \\
\text { Francis }\end{array}$ & 24 \\
\hline 11. & $\begin{array}{l}\text { Journal Of } \\
\text { Business And } \\
\text { Psychology }\end{array}$ & 3.17 & $\begin{array}{l}\text { https://link.springer.com/journ } \\
\text { al/10869 }\end{array}$ & $\begin{array}{l}\text { Kluwer } \\
\text { Academic/Ple } \\
\text { num } \\
\text { Publishers }\end{array}$ & 36 \\
\hline 12. & $\begin{array}{l}\text { International } \\
\text { Journal Of } \\
\text { Human } \\
\text { Resource } \\
\text { Management }\end{array}$ & 2.71 & $\begin{array}{l}\text { https://www.tandfonline.com/t } \\
\text { oc/rijh20/current }\end{array}$ & Routledge & 58 \\
\hline 13. & $\begin{array}{l}\text { Journal Of } \\
\text { Managerial } \\
\text { Psychology }\end{array}$ & 2.05 & $\begin{array}{l}\text { https://www.emerald.com/insi } \\
\text { ght/publication/issn/0268- } \\
3946\end{array}$ & $\begin{array}{l}\text { Emerald } \\
\text { Group } \\
\text { Publishing } \\
\text { Ltd. }\end{array}$ & 34 \\
\hline 14. & $\begin{array}{l}\text { Journal Of } \\
\text { Applied Social } \\
\text { Psychology }\end{array}$ & 1.99 & $\begin{array}{l}\text { https://onlinelibrary.wiley.com } \\
\text { /journal/15591816 }\end{array}$ & $\begin{array}{l}\text { Wiley- } \\
\text { Blackwell }\end{array}$ & 27 \\
\hline 15. & $\begin{array}{l}\text { Personnel } \\
\text { Review }\end{array}$ & 1.95 & $\begin{array}{l}\text { https://www.emeraldgrouppub } \\
\text { lishing.com/products/journals/ } \\
\text { journals.htm?id=PR }\end{array}$ & Emerald & 24 \\
\hline 16. & $\begin{array}{l}\text { Human } \\
\text { Performance }\end{array}$ & 1.9 & $\begin{array}{l}\text { https://www.tandfonline.com/l } \\
\text { oi/hhup20 }\end{array}$ & $\begin{array}{l}\text { Taylor \& } \\
\text { Francis }\end{array}$ & 20 \\
\hline 17. & $\begin{array}{l}\text { Psychological } \\
\text { Reports }\end{array}$ & 1.11 & $\begin{array}{l}\text { https://journals.sagepub.com/h } \\
\text { ome/prx }\end{array}$ & SAGE & 20 \\
\hline 18. & $\begin{array}{l}\text { Social Behavior } \\
\text { And Personality }\end{array}$ & 0.8 & $\begin{array}{l}\text { https://www.sbp- } \\
\text { journal.com/index.php/sbp }\end{array}$ & $\begin{array}{l}\text { Society for } \\
\text { Personality } \\
\text { Research }\end{array}$ & 25 \\
\hline
\end{tabular}

Table S3: The top 50 most productive institutions in Organizational Citizenship Behaviour Research

\begin{tabular}{|l|l|l|c|}
\hline \multicolumn{1}{|c|}{ Institution } & \multicolumn{1}{c|}{ Country } & No. of Publications \\
\hline $\mathbf{1 .}$ & Michigan State University & United States & 38 \\
\hline $\mathbf{2 .}$ & University of Haifa & Israel & 36 \\
\hline $\mathbf{3 .}$ & Indiana University & Indiana & 35 \\
\hline $\mathbf{4 .}$ & Hong Kong Polytechnic University & Hong Kong & 27 \\
\hline $\mathbf{5 .}$ & Pennsylvania State University & United States & 25 \\
\hline $\mathbf{6 .}$ & Chinese University of Hong Kong & Hong Kong & 25 \\
\hline $\mathbf{7 .}$ & Erasmus University Rotterdam & Netherlands & 25 \\
\hline $\mathbf{8 .}$ & Monash University & Australia & 19 \\
\hline $\mathbf{9 .}$ & Islamic Azad University & Iran & 19 \\
\hline $\mathbf{1 0 .}$ & Northern Illinois University & United States & 18 \\
\hline $\mathbf{1 1}$. & Lingnan University, Hong Kong & Hong Kong & 18 \\
\hline $\mathbf{1 2 .}$ & Renmin University of China & China & 18 \\
\hline
\end{tabular}




\begin{tabular}{|c|c|c|c|}
\hline 13. & University of Toronto & Canada & 18 \\
\hline 14. & The University of Georgia & United States & 18 \\
\hline 15. & Université Laval & Canada & 18 \\
\hline 16. & Kansas State University & United States & 17 \\
\hline 17. & University of South Florida, Tampa & United States & 17 \\
\hline 18. & Sun Yat-Sen University & China & 17 \\
\hline 19. & University of the Punjab, Lahore & Pakistan & 17 \\
\hline 20. & Universiti Sains Malaysia & Malaysia & 16 \\
\hline 21. & Purdue University & Indiana & 16 \\
\hline 22. & Seoul National University & South Korea & 16 \\
\hline 23. & Hong Kong Baptist University & Hong Kong & 16 \\
\hline 24. & Texas A\&M University & United States & 16 \\
\hline 25. & University of Oklahoma & United States & 16 \\
\hline 26. & Zhejiang University & China & 15 \\
\hline 27. & Universiti Teknologi Malaysia & Malaysia & 15 \\
\hline 28. & University of Illinois at Chicago & United States & 15 \\
\hline 29. & University of New South Wales UNSW Australia & Australia & 15 \\
\hline 30. & Griffith University & Australia & 15 \\
\hline 31. & Florida State University & United States & 14 \\
\hline 32. & Texas Christian University & United States & 14 \\
\hline 33. & Clemson University & United States & 14 \\
\hline 34. & Temple University & United States & 14 \\
\hline 35. & McMaster University & Canada & 14 \\
\hline 36. & University of Illinois at Urbana-Champaign & United States & 13 \\
\hline 37. & Universiteit van Amsterdam & Netherlands & 13 \\
\hline 38. & Loyola University of Chicago & United States & 13 \\
\hline 39. & University of Wisconsin-Eau Claire & United States & 13 \\
\hline 40. & Handelshøyskolen BI & Norway & 13 \\
\hline 41. & Auburn University & United States & 13 \\
\hline 42. & National University of Singapore & Singapore & 13 \\
\hline 43. & University of Michigan, Ann Arbor & United States & 13 \\
\hline 44. & Payame Noor University & Iran & 13 \\
\hline 45. & Universiteit Gent & Belgium & 13 \\
\hline 46. & University of South Florida System & United States & 13 \\
\hline 47. & Ohio State University & United States & 12 \\
\hline 48. & Arizona State University & United States & 12 \\
\hline 49. & Australian National University & Australia & 12 \\
\hline 50. & Western University & Canada & 12 \\
\hline
\end{tabular}

